\title{
The Future of Risk Management
}




\section{CRITICAL STUDIES IN RISK AND DISASTER}

Kim Fortun and Scott Gabriel Knowles, Series Editors

Critical Studies in Risk and Disaster explores how environmental, technological, and health risks are created, managed, and analyzed in different contexts.

Global in scope and drawing on perspectives from multiple disciplines, volumes in the series examine the ways that planning, science, and technology are implicated in disasters. The series also engages public policy formation-including analysis of science, technology, and environmental policy as well as welfare, conflict resolution, and economic policy developments where relevant. 


\title{
The Future of RISK MANAGEMENT
}

\author{
Edited by \\ Howard Kunreuther, \\ Robert J. Meyer, \\ and Erwann 0. Michel-Kerjan
}

$\overline{\text { PENN }}$

UNIVERSITY OF PENNSYLVANIA PRESS

PHILADELPHIA 
Copyright (@ 2019 University of Pennsylvania Press

All rights reserved. Except for brief quotations used for purposes of review or scholarly citation, none of this book may be reproduced in any form by any means without written permission from the publisher.

\author{
Published by \\ University of Pennsylvania Press \\ Philadelphia, Pennsylvania 19104-4112 \\ www.upenn.edu/pennpress \\ Printed in the United States of America \\ on acid-free paper \\ $\begin{array}{llllllllll}10 & 9 & 8 & 7 & 6 & 5 & 4 & 3 & 2 & 1\end{array}$ \\ Library of Congress Cataloging-in-Publication Data
}

Names: Kunreuther, Howard, editor. | Meyer, Robert J. (Robert John), editor. | Michel-Kerjan, Erwann, editor.

Title: The future of risk management / edited by Howard Kunreuther, Robert J. Meyer, and Erwann O. Michel-Kerjan

Other titles: Critical studies in risk and disaster.

Description: 1st edition. | Philadelphia: University of Pennsylvania Press, [2019] | Series: Critical studies in risk and disaster | Includes bibliographical references and index.

Identifiers: LCCN 2018054752| ISBN 9780812251326 (hardcover: alk. paper) | ISBN 0812251326 (hardcover: alk. paper)

Subjects: LCSH: Risk management. | Risk (Insurance) | InsuranceDecision making. | Emergency management.

Classification: LCC HD61 .F88 2019 | DDC 368-dc23

LC record available at https://lccn.loc.gov/2018054752 